\title{
Expression Analysis and Nuclear Import Study of Full-length Isoforms Importin $\alpha$ as 6x Histidin-tagged Fusion Protein on the Intracellular Localization of Recombinant HBV Core Protein
}

\author{
Aris Haryanto \\ Department of Biochemistry, Faculty of Veterinary Medicine, Gadjah Mada University, Yogyakarta, \\ Indonesia.
}

\section{Abstract}

\begin{abstract}
Isoform importin $\alpha$ molecules play a central role in the classical nuclear import pathway, that occurs through the nuclear pore complex (NPC) and typically requires a specific nuclear localization signal (NLS). In this study, it was investigated the role of isoforms importin $\alpha$ in the nuclear import of wild type recombinant hepatitis B virus core protein (WT $\mathrm{rHBc}$ ), phosphorylated recombinant $\mathrm{HBV}$ core $(\mathrm{rHBc}$ ) and recombinant HBV core without NLS by co-immunoprecipitation. Four recombinant full-length isoforms importin $\alpha$ as $6 x$ histidin-tagged fusion protein were expressed and analysed from expression plasmid vectors Rch1, pHM 1969, pHM 1967 and pHM 1965. The results indicated that importin $\alpha-1$, importin $\alpha-3$, importin $\alpha-4$ and importin $\alpha-5$ can be expressed and isolated from E. coli transformed recombinant DNA plasmid as protein in size around 58-60 kDa. By the nuclear transport study shown that isoforms importin $\alpha$ are involved in the nuclear import of WT rHBc, phosphorylated rHBc and rHBc without NLS. It also indicated that they have an important role for nuclear transport of from cytoplasm into the nucleus.
\end{abstract}

Keywords: NPC, NLS, importin $\alpha$, importin $\beta$, isoforms importin $\alpha$ as $6 x$ histidin-tagged fusion protein, WT rHBc, SV40 Tag, co-immunoprecipitation, westernblotting.

\section{Introduction}

Nuclear import of cellular protein and other macromolecules from cytoplasm into the nucleus is mediated by soluble cytosolic receptor protein that recognize and bind nuclear localization signals (NLS) (Görlich and Kutay, 1999). NLSs are characterized by short, single or bipartite stretches of basic amino acids. The first prototype sequences of NLS were identified in the $\mathrm{T}$ antigen of simian virus 40 (SV40 Tag) as amino sequences PKKKRKV and as KRPAATKKAGQAKKK in nucleoplasmin. Both of NLSs are primary sequences which

Corresponding author: Aris Haryanto, Department of Biochemistry, Faculty of Veterinary Medicine, Gadjah Mada University, Jl. Olah Raga Karangmalang, Yogyakarta 55281, Indonesia. Tel: 62-274-560865; Email: arisharyanto@yahoo.com characterized as classical NLSs and their relative consensus motif have been formulated as $\mathrm{K}(\mathrm{K} / \mathrm{R}) \mathrm{x}$ - (K/R)(Dang and Lee, 1989; Chelsky et al., 1989; Makkerh et al., 1996).

In the nuclear import, protein containing classical NLSs is mediated by binding to the cytosolic NLS receptor protein called importin $\alpha$ or karyopherin $\alpha$ (Görlich et al., 1994; Moroianu et al., 1995; Weis et al., 1996). Currently, six isoforms importin $\alpha$ have been identified in Human (Köhler et al., 1997). Importin $\alpha$ is heterodimers through its $\mathrm{N}$ terminus domain with protein importin $\beta$ also known as karyopherin $\beta$ whereby its affinity for the NLS is increased (Weis et al., 1996; Rexach and Blobel, 1995; Radu et al., 1995; Görlich et al., 1996). The receptor-cargo complex first binds through importin $\beta$ to components of the nuclear pore complex 
(NPC) and then transported through the nuclear envelope (Görlich et al., 1995; Moroianu et al., 1995).

Process of nuclear import has been proposed to be driven either by sequential interaction of increasing affinity importin $\beta$ with different nucleoporins along the central channel of the NPC or by the hydrophobic meshwork composed by nucleoporin (Ribbeck and Görlich, 2001; Ben-Efraim and Gerace, 2001). The import process is completed by binding of Ras-related nuclear protein in its GTP-bound form to the importin $\beta$ which results in the disassembly of the receptor cargo complex in the nucleus (Rexach and Blobel, 1995; Görlich et al., 1996).

The nucleus and cytoplasm are separated by the double membrane of the nuclear envelope. The outer membrane is continuously connected with the membrane of the endoplasmic reticulum. Transport between the cytoplasm and the nucleoplasm is highly regulated and occurs through protein-lined aqueous channels called nuclear pore complexes. This transport is facilitated by soluble transport receptors. The best study receptors belong to the importin $\beta$ superfamily. While importin $\beta$ can directly bind to a karyophilic cargo if it exposes an importin $\beta$ binding domain (IBB), the indirect binding via the adapter protein importin $\alpha$ to a NLS seems to be the most abundant pathway. Both, IBB and NLS consist of multiple basic amino acids. A second member of the importin $\beta$ superfamily is transportin that binds directly to the cargo via a leucine-rich M-9 domain as it is found on protein A1 of the hnRNP complex. Further not as well characterized transport receptors comprise the proteins NTF2, importin $\alpha-5$, RanBP6, importin $\alpha-7$ and transportin SR (Fried and Kutay, 2003). Classical pathway of nuclear import protein can be seen more detail in Figure 1.

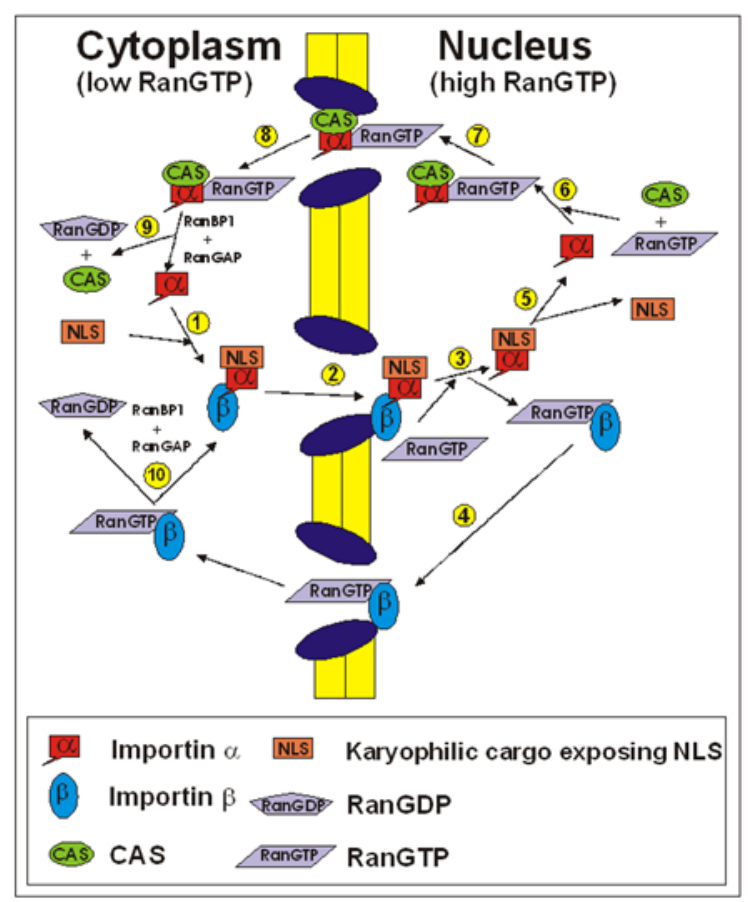

Figure 1. Pathway of the nuclear import cycle. 1) Importin $\alpha$ binds to the NLS of a karyophilic cargo followed by Importin $\beta$ binding to the complex. 2) Importin $\beta$ mediates contact with NPC and the import of cargo/importin $\alpha$ /importin $\beta$ complex from the cytoplasmic to the nuclear side of NPC. 3) Nuclear import is terminated by binding of RanGTP to importin $\beta$, which releases the complex from the NPC. 4) The importin $\beta$-RanGTP complex can directly exit from the nucleus. 5) Importin $\alpha$ releases karyophilic cargo. 6) Importin $\alpha$ binds to CAS and RanGTP for its re-export. 7) Importin $\alpha /$ CAS/RanGTP complex is exported to the cytoplasm through the NPC. 8) In the cytoplasm, Importin $\alpha /$ CAS/RanGTP complex is disassembled by hydrolysis of GTP to GDP. This reaction is catalysed by RanGAP and supported by RanBP1. 9) Importin $\alpha$ is released from Importin $\alpha$ / CAS/RanGTP complex. 10) Similarly, importin $\beta$ is disassembled. Importin $\alpha$ and $\beta$ can recombine for the next round of another cargo protein. Figure adapted from Görlich and Kutay (1999).

In this study, the recombinant fulllength isoforms importin $\alpha$ as 6x histidintagged fusion protein were expressed and analysed from some expression plasmid pHM 1969, pHM 1967, pHM 1965 and Rch1. By co-immunoprecipitation, we investigated 
the role of isoforms importin $\alpha$ in the nuclear import of wild type recombinant hepatitis B virus core protein, phosphorylated recombinant hepatitis $B$ virus core protein and recombinant hepatitis $B$ virus core without NLS.

In this study, the recombinant fulllength isoforms importin $\alpha$ as $6 x$ histidintagged fusion protein were expressed and analysed from some expression plasmid pHM 1969, pHM 1967, pHM 1965 and Rch1. By co-immunoprecipitation, we investigated the role of isoforms importin $\alpha$ in the nuclear import of wild type recombinant hepatitis B virus core protein, phosphorylated recombinant hepatitis $B$ virus core protein and recombinant hepatitis $B$ virus core without NLS.

\section{Materials and Methods Samples Preparation}

Recombinant DNA plasmid derived from pQE30, that carries full length of importin $\alpha-3$ (pHM 1969) and importin $\alpha-4$ (pHM 1967). Whereas recombinant DNA plasmid from pSE420, that carries importin $\alpha-5$ (pHM 1965). The DNA samples were sent by filter paper from Institute of Clinical and Molecular Virology, Erlangen, Nuernberg, Germany, then the filter paper with DNA samples were cut with scissors and diluted in $200 \mu \mathrm{H} \mathrm{H}_{2} \mathrm{O}$ in E-cup. The DNAs are ready to transform into competent $E$. coli. Transformation was performed by adding 10 $\mu l$ plasmid DNA into $50 \mu \mathrm{l}$ competent $E$. coli in $1.5 \mathrm{ml}$ E-cup. After gently shaking to mix the content, E-cup was stored on ice for 10 min. A heat shock was performed by preheated the E-cup at $42^{\circ} \mathrm{C}$ for 2 min on the heat block. Then into the E-cup was added 1 $\mathrm{ml}$ LB liquid medium and incubated in shaking incubator (INFORS-Bottmingen) at $37^{\circ} \mathrm{C}$ for $1 \mathrm{~h}$. The transformed competent cells were platted onto agar plate LB medium containing $30 \mu \mathrm{g} / \mathrm{ml}$ ampicillin. The plate was leaved at $37^{\circ} \mathrm{C}$ until the liquid has been absorbed. Then the plate was inverted and incubated over night at $37^{\circ} \mathrm{C}$. The E. coli culture was grown at $37^{\circ} \mathrm{C}$ over night. After 16 hours the bacterial colonies were picked and grown into $5 \mathrm{ml}$ LB medium containing ampicillin. The $E$. coli culture were incubated at $37^{\circ} \mathrm{C}$ over night in shaking incubator.

\section{Expression of 6x Histidin Tagged - importin Fusion $\alpha$ Protein}

The E. coli cultures were grown into 200 $\mathrm{ml}$ ampicillin containing LB medium (100 $\mathrm{mg} /$ liter). The bacteria cultures were incubated at $37^{\circ} \mathrm{C} 12-16 \mathrm{~h}$ in shaking incubator till optical density (OD) reaches 0.9 at fixed wave length $600 \mathrm{~nm}$. The expression of 6x histidin-tagged - importin fusion protein were induced by adding IPTG to a final concentration of $2 \mathrm{mM}$. The bacteria were allowed to grow for an additional $3 \mathrm{~h}$ at $37^{\circ} \mathrm{C}$ in shaking incubator. To stop the bacterial growing, the bacteria cultures were cooled in ice for $10 \mathrm{~min}$. Then the cells were centrifuged at $4,500 \mathrm{rpm}$ for $10 \mathrm{~min}$. Supernatant was removed and the pellet was resuspended with $3.75 \mathrm{ml}$ lysis buffer $(75 \mu \mathrm{l}$ leucopeptin $20 \mu \mathrm{g} / \mathrm{ml} ; 37.5 \mu \mathrm{l}$ chymostatin $10 \mu \mathrm{g} / \mathrm{ml} ; 1.275 \mu \mathrm{l} \beta$-merchaptoethanol 5 $\mathrm{mM} ; 3.14 \mu \mathrm{l}$ Tris- $\mathrm{HCl} 200 \mathrm{mM}$; $\mathrm{NaCl} 500 \mathrm{mM}$ ). To destroy the cell wall, the resuspended pellet was frozen in liquid nitrogen and thawed directly at $37^{\circ} \mathrm{C}$ in water bath. This step was repeated three times, then the cells were homogenized by sonicating in the ultrasonic sonicator (70\% maximal capacity) for $60 \mathrm{~s}$ three times. The cells were kept on ice at all times. After that the cells were centrifuged at $15,000 \mathrm{rpm}$ at $4^{\circ} \mathrm{C}$ for $20 \mathrm{~min}$.

\section{Equilibration of Nickel-NTA Agarose}

Nickel-NTA agarose beads $2.5 \mathrm{ml}(5 \mathrm{ml}$ suspension) were placed in $15 \mathrm{ml}$ conical tubes. After three times was washed with PBS, the tubes were equilibrated with $5 \mathrm{ml}$ 
equilibration buffer ( $\mathrm{NaCl} 500 \mathrm{mM} /$ Imidazole $10 \mathrm{mM}$ pH 7.0). Meanwhile, the homogenate were added with imidazole 10 $\mathrm{mM} \mathrm{pH}$ 7.6. Then the homogenate/ imidazole were mixed with $5 \mathrm{ml}$ Nickel-NTA agarose and incubated at $4^{\circ} \mathrm{C}$ for $1 \mathrm{~h}$. The mixture were applied to the plastic spuit and allowed by gravity flow. The mixture was collected again in the $15 \mathrm{ml}$ conical tube and repeated this step three times. The plastic tubes were washed with $\mathrm{NaCl} 500 \mathrm{mM} /$ imidazole $10 \mathrm{mM}$ pH 7.0 until the OD $280<$ 0.01 . The proteins were eluted from agarose beads with $40 \mathrm{ml}$ imidazole gradient (imidazole 30 - $500 \mathrm{mM} / \mathrm{NaCl} 500 \mathrm{mM} \mathrm{pH}$ 7.0). The supernatant were collected in several fractions, $1 \mathrm{ml}$ per-fraction. The fractions are ready to run on SDS Page, then the SDS Page gel was stained by coomasie blue and silver nitrate staining.

\section{Staining of SDS-Page Gels by Silver Nitrate}

SDS-Page gel was incubated over night at room temperature in 50\% methanol solution with gentle shaking. Solution was removed and washed with $\mathrm{H}_{2} \mathrm{O}$ and changed every $15 \mathrm{~min}$. The gel was incubated for 20 min in silver nitrate solution (mixture solution between solution A (1.55 $\mathrm{g} \mathrm{AgNO}_{3}$ in $\left.8 \mathrm{ml} \mathrm{H} \mathrm{H}_{2} \mathrm{O}\right)$ and Solution $\mathrm{B}\left(38.2 \mathrm{ml} \mathrm{H} \mathrm{O}_{2}\right.$; $3.8 \mathrm{ml} 1 \mathrm{~N} \mathrm{NaOH} ; 2.8 \mathrm{ml}$ Ammonia 25\%). Again the gels was washed with $\mathrm{H}_{2} 0$ for 10 $\mathrm{min}$. Then the gels was immersed in reducer solution ( $50 \mathrm{mg}$ Citroen acid, $0.7 \mathrm{ml}$ formalin $37 \%$ diluted in 1 liter $\mathrm{H}_{2} \mathrm{O}$ ) until the desired contrast is obtained. The desired bands were fixed by fixation solution (from photo laboratorium). The gel was washed with $\mathrm{H}_{2} \mathrm{O}$ and dried on the filter paper whatman at $80^{\circ} \mathrm{C}$ for $2 \mathrm{~h}$.

\section{Co-immunoprecipitation of Isoforms Importin $\alpha$}

For co-immunoprecipitation, Dako anti core HBV antibody was bound to the
Dynabeads M-280 sheep anti rabbit IgG (superparamagnetic polystyrene). Five $\mu \mathrm{l}$ Dako antibody was added in $60 \mu \mathrm{l}$ Dynabeads M-280 sheep anti rabbit IgG. Then they were incubated at $4^{\circ} \mathrm{C}$ over night on rotating roller. Next day, Dynabeads/ Dako complex was washed with $70 \mu \mathrm{l}$ PBS four times on magnetic stander. The Dynabeads/Dako was devided in three reaction tube. The first reaction was added $55 \mu \mathrm{l}$ protein of $\mathrm{HBV}-$ Core wild type $(0.46$ $\mu \mathrm{g} / \mu \mathrm{l})$, the second reaction was added 12.5 $\mu \mathrm{l}$ phosphorylation Core protein $(110 \mathrm{ng} / \mu \mathrm{l})$ as positive control and the third one was added $2.4 \mu \mathrm{l}$ core protein without NLS (1.03 $\mu \mathrm{g} / \mu \mathrm{l})$ as negative control. In each reaction was added $0.5 \mu \mathrm{g}$ importin $\alpha-1 ; \alpha-3, \alpha-4, \alpha-5$ that diluted in $500 \mathrm{mM}$ imidazole $/ \mathrm{NaCl} \mathrm{pH}$ 7.0 and $200 \mu \mathrm{l}$ reaction buffer $\left(2.88 \mathrm{ml} \mathrm{H} \mathrm{H}_{2} \mathrm{O}\right.$; $30 \mu \mathrm{l} \mathrm{BSA} 10 \% / \mathrm{H}_{2} \mathrm{O} ; 7.5 \mu \mathrm{l} \mathrm{MgCl}{ }_{2} ; 7.5 \mu \mathrm{l} 1 \mathrm{M}$ Tris $\mathrm{pH} 7.5 ; 6 \mu \mathrm{l} 1 \mathrm{M}$ DTT). All of reactions were incubated at $4{ }^{\circ} \mathrm{C}$ over night on rotating roller. Next day, each reaction was washed with $300 \mu \mathrm{l}$ transport buffer two times on magnetic stirer and then with $300 \mu \mathrm{l}$ transport buffer $/ 0.1 \%$ NP-40. After changing E-cup, washed again three times with $300 \mu \mathrm{l}$ transport buffer on magnetic stirer. The reaction tubes were centrifuged at 14,000 rpm for $30 \mathrm{~min}$ and pellet was resuspended by $5 \mu \mathrm{l} \mathrm{H}_{2} \mathrm{O} ; 5 \mu \mathrm{l}$ loading buffer; $1.5 \mu \mathrm{l} 1 \mathrm{M}$ DTT. The samples are ready to run on SDS Page and stained by coomasie blue and silver nitrate staining.

\section{Westernblotting}

Westernblotting or immunoblotting is used to identify specific antigens recognized by polyclonal or monoclonal antibodies. Proteins samples are solubilized, usually with SDS and reducing agent such as DTT or $\beta$-mercaptoethanol. Following solubilization, the material is separated by SDS Page. The proteins are then electrophoretically transferred in tank to PVDF membrane. The transferred proteins 
are bound to the surface of the membrane, providing acess for reaction with immunodetection reagents. All remaining binding sites are blocked by immersing the membrane in a solution containing either a protein or detergent blocking agent. After probing with the primary antibody, the membrane is washed and the antibodyantigen complexes are identified with horseradish peroxidase enzymes coupled to the secondary anti-IgG antibody. Luminescent substrates are then used to visualized the activity.

\section{Transfer of Protein from SDS Page Gel to PVDF Membrane}

A tank was filled with transfer buffer and placed cassette containing sandwich into electroblotting apparatus in correct orientation. Leads of power supply was connected to corresponding anode and cathode sides of electroblotting apparatus. The electrophoretically transfer proteins from gel to membrane is over night at $300 \mathrm{~V}$, $40 \mathrm{~mA}$ (constant) with cooling at $4^{\circ} \mathrm{C}$. Next day the power supply was turned off and disassembled the apparatus. Membrane was removed from blotting apparatus and noted orientation by cutting a corner with scissors.

\section{Immunodetection}

PVDF membrane with transferred proteins were immersed in blocking buffer (5\% milk/PBS) at room temperature for $1 \mathrm{~h}$ to fill all protein binding sites with a nonreactive protein or detergent. $5 \mu$ primary antibody anti importin $\alpha$ from mouse was diluted in $10 \mathrm{ml}$ blocking buffer (dilution $1: 2,000)$. PVDF membrane with $10 \mathrm{ml}$ blocking buffer were placed in heat-sealable plastic bag then sealed the plastic bag. Then it was incubated at room temperature for 3 $h$ with constant agitation on a rocking platform. After $3 \mathrm{~h}$, the PVDF membrane was removed from plastic bag with pinset and placed in plastic box. It was washed three times with washing buffer $(0.5 \%$ milk/ PBS; 0.1\% Tween-20) by agitating $10 \mathrm{~min}$ each times. Two $\mu$ l secondary antibody peroxidase (POD) anti mouse conjugated was diluted in $10 \mathrm{ml}$ blocking buffer (dilution 1:5,000). Then the membrane PVDF was placed in new heat-sealable plastic bag and incubated $1 \mathrm{~h}$ at room temperature with constant agitation. After $1 \mathrm{~h}$, the PVDF membrane was removed from plastic bag with pinset and placed in plastic box. It was washed three times with washing buffer and once with PBS by agitating for $10 \mathrm{~min}$ each times. PVDF Membrane was placed in new heat-sealable plastic bag and developed for $2 \mathrm{~min}$ in a luminescent substrate solution containing luminol for peroxidase system. In dark room, the membrane PVDF was placed face down onto film. In film cassette, the film was exposed for a few second to several minutes. Finally, the exposed film was developed using development machine.

\section{Results and Discussion \\ SDS-PAGE Gel Electrophoresis}

Firstly, to express the full length isoforms importin a as $6 x$ histidin-tagged fusion protein, E. coli containing recombinant DNA plasmid pHM 1969, pHM 1967 and pHM 1965 for importin $\alpha-3, \alpha-4, \alpha-5$ respectively and Rch1 for importin $\alpha-1$ were grown into liquid LB medium in presence of ampicillin $(10 \mu \mathrm{g} / \mu \mathrm{l})$. Then to induce the protein expression IPTG was added to final concentration of $2 \mathrm{mM}$. Soluble expressed protein was harvested by destruction of the cell wall $E$. coli by sonication in presence of protease inhibitor. The full length isoforms importin $\alpha$ as 6x histidin-tagged fusion protein was isolated by protein affinity chromatography in Nickel-NTA agarose beads. The purification protein was collected by several fraction in $1 \mathrm{ml}$ volume per sample. Using Nanosep $10 \mathrm{~K}$ the soluble protein was concentrated. By coomasie blue staining of SDS-PAGE gel shown that 
isoform importin a as 6x histidin-tagged fusion protein with molecular weight $58 \mathrm{kDa}$ found in fraction 1, 2, 3 and 4 (Figure 2). In comparison the serial dilution of BSA standard (MW $66 \mathrm{kDa}$ ) was run in lane 5, 6, 7 and 8.

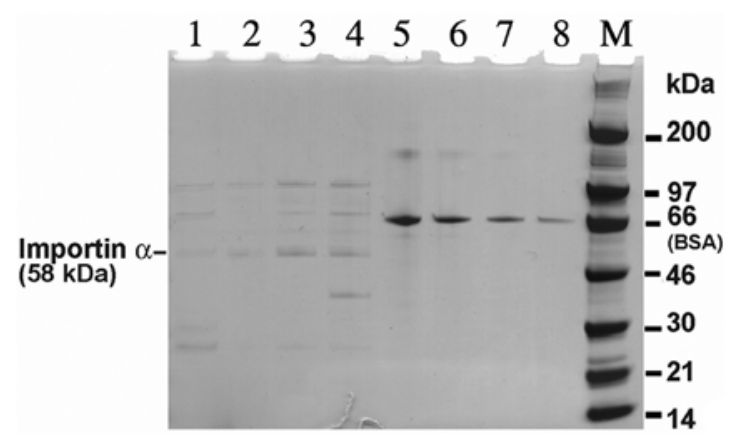

Figure 2. Coomassie blue staining of isoforms importin $\alpha$ as $6 x$ histidin-tagged fusion protein after concentrated using Nanosep $10 \mathrm{~K}$. The histidin tagged importin $\alpha$ have a molecular weight $58 \mathrm{kDa}$. M indicated the rainbow marker RPN756 as molecular weight marker of protein. Sample no 1 is importin $\alpha-$ 1 , sample no 2 is importin $\alpha-3$, sample no 3 is importin $\alpha-4$ and sample no 4 is importin $\alpha-5$. The serial dilution of BSA in PBS in sample no 5 in $1 \mu \mathrm{g} / \mu \mathrm{l}$, no 6 in 0.5 $\mu \mathrm{g} / \mu \mathrm{l}$, no 7 in $0.25 \mu \mathrm{g} / \mu \mathrm{l}$, and no 8 in $0.125 \mu \mathrm{g} / \mu \mathrm{l}$.

Importin $\alpha$ is characterized adapter protein that mediated nuclear import by binding to the cargoes in the cytoplasm via recognition of NLS. Importin-cargo complex imported through the NPC via interactions with NPC protein called nucleoporin. In the nucleus, importin encounters RanGTP and the ensuing importin-RanGTP complex leads to dissociation of the cargo from the importin, whereby the importin is recycled back to the cytoplasm. Importin $\alpha$ bears a striking resemblance to that of importin $\beta$ and transportin (Conti et al., 1998; Kobe 1999). The NLS binding domain consists of 10 Armadillo motif stacked into a righthanded superheliks, and repeat 2 to 5 can be superimposed well onto HEAT repeat 9 to 12 of importin $\beta$. The NLS sits in the concave inner groove of importin $\alpha$, which is lined with conserved tryptophan and asparagin residues. There are two binding pockets, a major one formed by Arm 2 to 4, occupied by monopartite NLSs and a second closer to the C-terminus (Arm 7 to 8), that can be occupied by the N-terminus portion of bipartite NLS (Conti and Kuriyan, 2000). The N-terminus of importin $\alpha$, which contains the IBB domain is not structured in the isolated protein, although a short stretch of basic residues contacts the major NLS binding pocket and may function as an autoinhibitor of cargo loading (Conti et al., 1998; Kobe 1999).

Staining of SDS-PAGE by coomasie blue did not give clearly bands of protein, therefore silver nitrate staining was performed to visualize the clearer protein bands in SDS PAGE gel. Electrophoresis of isoforms importin $\alpha$ as $6 x$ histidin-tagged fusion proteins then can be seen more detail in Figure 3. By silver nitrate staining protein bands of importin $\alpha-1, \alpha-3, \alpha-4$ and $\alpha-5$ are located between 46 and $66 \mathrm{kDa}$ of marker protein RPN756.

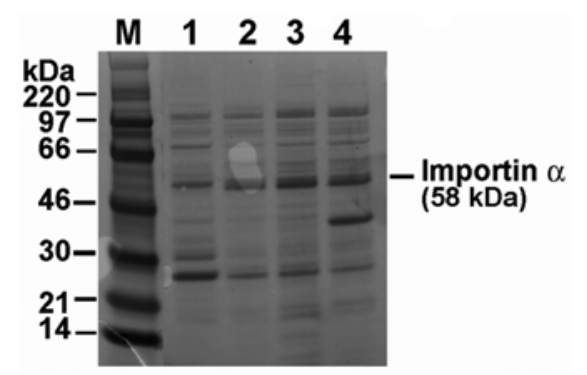

Figure 3. SDS-Page of isoforms importin $\alpha$ as $6 x$ histidin-tagged protein after silver nitrate staining. The 6x histidin-tagged-importin $\alpha$ have molecular weight $58 \mathrm{kDa}$. Sample no 1 is importin $\alpha-1$, no 2 is importin $\alpha-3$, no 3 is importin $\alpha-4$ and no 4 is importin $\alpha-5$. $M$ indicated a rainbow marker RPN756 as molecular weight marker of protein.

Silver nitrate staining is more sensitive than coomasie blue staining and capable of detecting as little as 0.1 - $1 \mathrm{ng}$ of polypeptide in single band. This staining is easier to 
prepare and does not generate potentially explosive by products (Sammonds et al., 1981).

\section{Co-immunoprecipitation}

Co-immunoprecipitation is a classical method to detect protein-protein interaction. In this study, co-immunoprecipitation was used to detect interaction of the wild type recombinant $\mathrm{HBV}$ core (WT rHBc), phosphorylated recombinant $\mathrm{HBV}$ core (rHBc) and recombinant $\mathrm{HBV}$ core $(\mathrm{rHBc})$ without NLS with isoforms importin $\alpha$ as $6 \mathrm{x}$ histidin-tagged fusion protein, namely importin $\alpha-1$, importin $\alpha-3$, importin $\alpha-4$ and importin $\alpha-5$. The results indicated that isoforms importin $\alpha-1$, importin $\alpha-3$, importin $\alpha-4$ and importin $\alpha-5$ play an important role for nuclear localization of WT $\mathrm{rHBc}$, phosphorylated $\mathrm{rHBc}$ and $\mathrm{rHBc}$ without NLS. The role of isoforms importin $\alpha$ for nuclear import can be found in all lines on SDS-PAGE (no 1 until 17), see Figure 4.

In the nuclear import, importin $\alpha$ has function as an adaptor molecule by binding importin $\beta$ via its amino-terminally located importin $\beta$ binding (IBB) domain (Görlich et al., 1996; Weis et al., 1996) and by binding NLS bearing protein via its two NLS binding sites in central area (Conti et al., 1998; Herold et al., 1998). Importin $\beta$ is the transport receptor that carries the importin $\alpha-\mathrm{NLS}$ complex from the cytoplasm into the nuclear site of NPC (Görlich et al., 1995).

Nowadays, several isoforms of importin $\alpha$ in humans have been described, namely importin $\alpha-1$ from Rch1 (Cuomo et al., 1994), importin $\alpha-3$ from Qip (Seki et al., 1997), importin $\alpha-4$ from hSRP1 $\gamma$ (Nachury et al., 1998), importin $\alpha-5$ from hSRP1 and two newly reporting importin $\alpha$, namely importin $\alpha-6$ (Köhler et al., 1997) and importin $\alpha-7$, which is the human homologue of the recently identified mouse importin -S2 (Tsuji et al., 1997).

In the nuclear import, importin $\alpha$ has function as an adaptor molecule by binding importin $\beta$ via its amino-terminally located IBB domain (Görlich et al., 1996; Weis et al., 1996) and by binding NLS bearing protein via its two NLS binding sites in central area (Conti et al., 1998; Herold et al., 1998). Importin $\beta$ is the transport receptor that

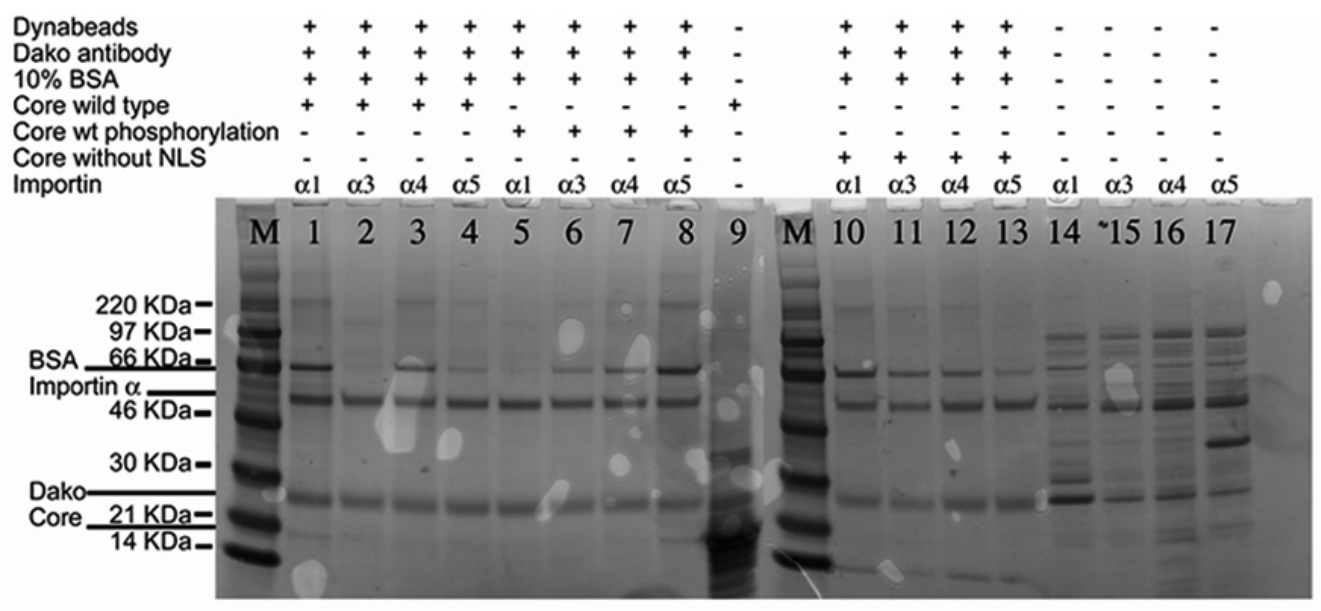

Figure 4. Co-immunoprecipitation of isoforms histidin tag-importin $\alpha$ fusion protein by silver nitrate staining. M indicated the molecular weight markers protein RPN756. Samples no 1 until 4 are immunoprecipited isoforms importin $\alpha$ with recombinant HBV Core wild type, no 5 untill 8 are immunoprecipited isoform importin $\alpha$ with phosphorylation HBV Core, no 9 is recombinat HBV Core wild type, no 10 untill 13 are immunoprecipted isoform importin $\alpha$ with HBV Core without NLS and no 14 untill 17 are importin $\alpha-1, \alpha-3, \alpha-4, \alpha-5$ respectively. 
carries the importin $\alpha-\mathrm{NLS}$ complex from the cytoplasm into the nuclear site of NPC (Görlich et al., 1995).

Nowadays, several isoforms of importin $\alpha$ in humans have been described, namely importin $\alpha-1$ from Rch1 (Cuomo et al., 1994), importin $\alpha-3$ from Qip (Seki et al., 1997), importin $\alpha-4$ from hSRP1 $\gamma$ (Nachury et al., 1998), importin $\alpha-5$ from hSRP1 and two newly reporting importin $\alpha$, namely importin $\alpha-6$ (Köhler et al., 1997) and importin $\alpha-7$, which is the human homologue of the recently identified mouse importin -S2 (Tsuji et al., 1997).

\section{Expression Analysis}

Analysis expression of isoforms 6x histidin-tagged importin $\alpha$ fusion protein was performed by Westernblotting. Each of the histidin-tagged importin $\alpha$ fusion protein was successfully purified from crude extracts of E. coli transformed recombinant DNA plasmid by Nickel-affinity chromatography using Nickel-NTA agarose under cold condition. As shown in figure 5, the isoforms 6x histidin-tagged importin $\alpha-1, \alpha-3, \alpha-4$ and $\alpha-5$ was expressed as protein bands in size of around $58 \mathrm{kDa}$. The size of these isoforms importin $\alpha$ is approximately similar with importin -3 which expressed as recombinant Glutathione-S-transferase fusion protein (GST-importin $\alpha-3$ ) by Haryanto (2004). The fusion proteins are located between 46 and $66 \mathrm{kDa}$ of marker protein RPN756. In figure 5 , the expressed isoforms importin $\alpha$ as $6 x$ histidin-tagged fusion protein can be detected by antibody anti importin $\alpha$ from mouse. The expression levels and the strength of expressed protein vary between the different of isoforms importin $\alpha$. Importin $\alpha-5$ is little bit higher than other importins in the range around $60 \mathrm{kDa}$. Expression of importin $\alpha-1$ is higher than the others.

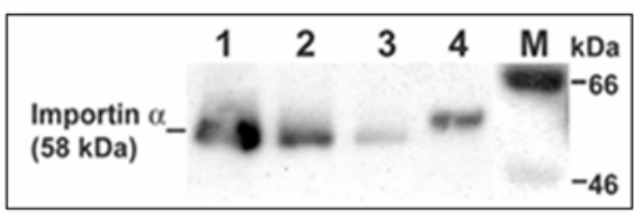

Figure 5. Immunedetection of isoform 6x histidin tagged importin $\boldsymbol{\alpha}$ fusion proteins. The isoforms histidin tagged importin $\boldsymbol{\alpha}$ fusion protein have molecular weight $58 \mathrm{kDa}$. Lane 1 is importin $\alpha-1$, lane 2 is importin $\alpha-3$, lane 3 is importin $\alpha-4$ and lane 4 is importin $\alpha-5$. M is Rainbow marker RPN756 used as molecular weight marker of protein.

Importin $\alpha$ is an adapter protein, which mediates import of protein that carry a classical NLS. Importin $\alpha$ binds both cargo and importin $\beta$ in the cytoplasm of the cell. Importin $\beta$ accounts for contact with the NPC and mediates translocalization of NLS/ importin $\alpha / \beta$ complex from the cytoplasmic to the nuclear side of the NPC (Görlich et al., 1996, Moroinau et al., 1995, Weis et al., 1996). In the classical nuclear import pathway, importin $\alpha$ recognizes and binds protein cargo in cytoplasm, linking it to importin $\beta$, then importin $\beta$ mediates interaction of the trimeric complex with the NPC as it translocates into the nucleus (Görlich et al., 1995). In the nucleus, the trimeric complex is dissociated by RanGTP. Binding of RanGTP to importin $\beta$ causes a conformational change that results in the release of importin $\alpha$ / protein cargo complex (Lee et al., 2005).

\section{Acknowledgements}

I would like to thank to Prof. Dr. Michael Kann, MD. from Institute of Medical Virology, Justus-Liebig-University, Giessen, Germany for an excellent and critical supervision. Greatly acknowledgment also to Dr. Peter Lischka from Institute of Clinical and Molecular Virology, ErlangenNürnberg, Germany for the kind gift of pHM 1965, pHM 1967, pHM 1969 plasmid vectors. This research was supported by Sonder 
Forschung Bereich (SFB) 535, Justus-LiebigUniversity, Giessen and Deutsche Akademische Austauschdienst (DAAD), Germany.

\section{References}

Ben-Efraim, I. and Gerace, L., 2001. Gradient of increasing affinity of importin $\beta$ for nucleoporins along the pathway of nuclear import. J. Cell. Biol., 152, 411418.

Chelsky, D., Ralph, R. and Jonak, G., 1989. Sequence requirements for synthetic peptide-mediated translocation to the nucleus. Mol. Cell. Biol., 9, 2487-2492.

Conti, E., Uy, M., Leighton, L., Blobel, G. and Kriyan, J., 1998. Crytallographic analysis of the recognition a nuclear localization signal by the nuclear import factor karyopherin alpha. Cell, 94, 193-104.

Conti, E. and Kuriyan, J., 2000. Crystallographic and lysis of specific yet versatile recognition of distint nuclear localization signal by karyopherin alpha. Structure, 8, 329338.

Cuomo, C.A., Kirch, S.A., Gyuris, J., Bread, R. and Oettinger, M.A., 1994. Rch1, a protein that specifially interacts with the RAG-1 recombination activating protein. Proc. Natl. Acad. Sci., 91, 61566160.

Dang, C.V. and Lee, W.H., 1989. Nuclear and nucleolar targeting sequences of c-erb A, c-myb, n-myc, p53, HSP70 and HIV tat proteins. J. Biol. Chem., 264, 1801918023.

Fried, H. and Kutay, U., 2003. Nucleocytoplasmic transport: taking an inventory. Cell. Mol. Life. Sci., 60, 1659-1688.

Görlich, D., Prehn, S., Laskey, R.A. and Hartmann, E., 1994. Isolation of a protein that is essensial for the first step of nuclear protein import. Cell 79, 767778.

Görlich, D., Vogel, F., Mills, A.D., Hartmann, E. and Laskey, R.A., 1995. Distinct functions for the two importin subunit in nuclear protein import. Nature, 377, 246-248.

Görlich, D., Henklein, P., Laskey, R.A. and Hartmann E., 1996. A 41 amino acid motif in importin alpha confers binding to importin beta and hence transit into the nucleus. EMBO J., 15, 1810-1817.

Görlich, D. and Kutay, U. 1999. Transport between the cell nucleus and the cytoplasm. Annu. Rev. Cell. Dev. Biol., 15, 607-660.

Haryanto, A., 2004. Generation and expression of recombinant glutathioneS-transferase full-length importin $\alpha-3$ (GST-importin $\alpha-3$ ) fusion protein and study of its role on the nuclear transport of protein. I. J. Biotech., ed. June. 681720.

Herold, A., Truant, R., Wiegand, H. and Cullens, B.R., 1998. Determination of the functional domain organisation of the importin alpha nuclear import factor. J. Cell. Biol., 143, 309-318.

Kobe, B., 1999. Autoinhibition by an internal nuclear localization signal revealed by the crystal structure of mammalian importin alpha. Nat. Struct. Biol., 6, 388397.

Köhler, M., Ansieau, S., Prehn, S., Leutz, A., Haller, H. and Hartmann, E., 1997. Cloning of two novel importin $\alpha$ subunit and analysis of the expression pattern of the importin $\alpha$ protein family. FEBS lett., 417, 104-108.

Lee, S.J., Matsuura, Y., Liu, S.M. and Stewart, M. 2005. Structural basis for nuclear import complex dissociation by RanGTP. Nature, 435 (7042), 693-696.

Makkerh, J.P., Dingwall, C. and Laskey, R.A. 1996. Comparative mutagenesis of nuclear localization signals reveals the 
importance of neutral and acidic amino acids. Curr. Biol., 6, 1025-1027.

Moroinau, J., Hijikata, M., Blobel, G, and Radu, A., 1995. Mamalian karyopherin $\alpha 1 \beta$ and $\alpha 2 \beta$ heterodimers: 1 or $\alpha 2$ subunit binds nuclear localization sequence and $\beta$ subunit interacts with peptide repeat containing nucleoporins. Proc. Natl. Acad. Sci., 92, 6532-6536.

Nachury, M.V., Ryder, U.W., Lamond, A.I. and Weis, K., 1998. Cloning and characterization of hSRPI $\gamma$, a tissuespecific nuclear transport factor. Proc. Natl. Acad. Sci., 95, 583-587.

Radu, A., Blobel, G., Moore, M.S., 1995. Identification of a protein complex that is required for nuclear protein import and mediates docking of import substrate to distinct nucleoporins. Proc. Natl. Acad. Sci., 92, 1769-1773.

Rexach and Blobel, 1995. Protein import into nuclei: association and dissociation reactions involving transport substrate, transport factor, and nucleoporins. Cell, 83, 683-692.
Ribbeck, K. and Görlich, D., 2001. Kinetic analysis of translocation through nuclear core complexes. EMBO J., 20, 1320-1330.

Sammonds, D.W., Adams, L.D., and Nishizawa, E.E., 1981. Ultrasensitive silver-based color staining of polypeptides in polyacrylamide gels. Elecrophoresis, 2, 135.

Seki, T., Tada, S., Katada, T. and Enomoto, T., 1997. Cloning of a cDNA encoding novel importin $\alpha$ homologue, Qip1: discrimination of Qip1 and Rch1 from hSrp1 by their ability to interact with DNA helicase Q1/RecQ1. Biochem. Biophys. Res. Commun., 234, 7633-7637.

Tsuji, L., Takumi, T., Imamoto, N. and Yoneda, Y., 1997. Identification of hSRP1 $\alpha$ as a functional receptor for nuclear localization sequences. Science, 268, 1049-1053.

Weis, K., Ryder, U. and Lamond, A.I., 1996. The conserved amino terminal domain of hSRPI $\alpha$ is essensial for nuclear protein import. EMBO J., 15, 1818-1825. 